\section{UNIVERSITY OF DEBRECEN}

FACULTY OF

HeALTH

NYÍREGYHÁZA

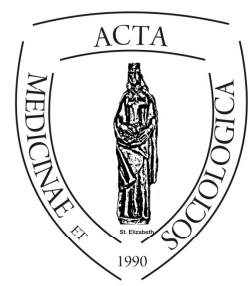

ACTA

MedSOC

VOLUME 7.

2016

\title{
Does the Hungarian child protection system provide appropriate responses to the problem of street children?
}

\author{
Hüse Lajos \\ Debreceni Egyetem Egészségügyi Kar \\ Szociális Munka Tanszék
}

\begin{abstract}
Absztrakt. Megfelelően reagál a magyarországi gyermekvédelmi rendszer az utcagyere-kek-problémára? A családoknak szánt szociális és gyermekvédelmi / gyermekjóléti szolgáltatások körét két alapvető törvény szabályozza Magyarországon: az 1993. évi III. törvény a szociális igazgatásról és szociális ellátásokról, valamint az 1997. évi XXXI. törvény a gyermekek védelméről és a gyámügyi igazgatásról (Gyermekvédelmi törvény). A szolgáltatások ingyenesek a rászoruló családok számára. Mivel mindkét terület a szabályozás értelmében teljes földrajzi lefedettséget és nagyszámú szolgáltatást biztosít, a területen egyre több képzett szociális munkás foglalkoztatására került sor. Ez a fokozatos fejlődés 2000-ben ért véget, amikortól a szociális munkás szakma új, innovatív beavatkozások és módszerek meghonosítására kezdett fókuszálni, melyeket a szolgáltatásokban alkalmazni tudnak. Az újdonságok egyike volt a gyermekjóléti utcai szociális munka. A tanulmány bemutatja, milyen erőfeszítések irányultak az utcagyerek-probléma megoldására.
\end{abstract}

Kulcsszavak: gyermekvédelem, utcagyerek, szociális munka

Abstract. In Hungary there are two basic laws regulating services allocated for families. One of them is the Act 3 of 1993 on social governance and social benefits and the other 
one is Act 31 of 1997 on Child Protection and guardian administration (referred to as the Child Protection Act). Social and child protection services available for families are free. Due to the regu-lations of both fields the geographical coverage and the number of services providing family care also expanded, and more and more qualified social workers were employed. This progressive development ended by the year 2000, and social workers focused on applying new interventions and methods tailored to a problem, and work out innovative new interventions within certain services. One of the new services focuses to the problem of street children. The article shows the efforts of solving street children.

Keywords: child protect system, streetchild, social work

DOI: $10.19055 / \mathrm{ams} .2016 .7 / 22-23 / 6$

\section{Introduction}

The current Hungarian child protection system was established almost twenty years ago. Owing to a lack of Hungarian precedents, the system had to be set up from scratch, based on international experience obtained mainly from the European Union member countries. The Hungarian system, aimed primarily at supporting families, is regarded by Hungarian experts as a well-structured one. Nevertheless beyond the well-structured system there are many problems interwoven the efforts aimed to child protection: underfunding; overburdened social workers; inadequate tools about the mayor social problem, the effects of extreme poverty. Through the structural establishment of the child protection system and its reform in terms of its approach and theory, significant progress has been made in countless areas - examples include the saturation of Hungarian legislation with the spirit of children's rights, the evolution of family support activities and the fight against child abuse - the weaknesses of child protection in Hungary are clearly visible.

The effectiveness of child protection in Hungary can be measured by looking at the lives of those children who have been pushed to the periphery of society together with their families, and, at the same time, are becoming more and more alienated from their own families as well. At the other hand, we have to consider while the disadvantaged groups are growing rapidly and the poverty is deepening, the dysfunctions also appears in a well-functioning child protection system, and its efficiency deteriorates. 


\section{The system of child protection in Hungary}

In 1989, the New York Convention designed what came to be known as children's rights. In 1991 in Hungary it was introduced by Act LXIV.

In the Budapest declaration UNICEF and the UN children's law organization summarized their experience from what was learned in Eastern Europe. According to the declaration:

- we need a policy and programmes that provide services, a stable society and economic possibilities for the children who grow up without the care of their family.

- it is necessary to design extensive social welfare reforms including economic policies that allow the equal growth and democratic atmosphere that inspires citizens to participate in the decisionmaking.

In 1997 Act XXXI was passed on the protection of children and the responsibilities of the guardian. This law was a milestone in the history of the protection system and the way in which children are taken care of. The purpose of the new legislation was to have an efficient system in place that would provide equal rights for every indigent child. This is a hierarchical system in which there is adherence to Hungarian and international principles and values.

The modern child protection system in Hungary focuses on 3 important tasks:

- helping to bring up the child in a family, promoting of the child's physical, emotional and intellectual development

- the prevention and impeding of child endangerment and mistreatment

- the assurance of substitute protection if it is necessary.

With the interests of children being its highest priority, the legislation on child protection differentiates between the levels of prevention, social support embodied in primary care, intervention by the authorities, and special services of child protection (Herczog, 2001).

On the level of prevention, an inter-branch safety network is established, in addition to financial support and benefits-in-kind, as well as child welfare service as a primary care system, with the purpose of preventing child endangerment and facilitating the bringing-up of children in families: it is called the child welfare reporting and monitoring network (Szöllösi, 2004).

Within the framework of the child welfare service offering personal care, a problem-solving system that utilizes the methodology of social work, as well as a sophisticated structure that monitors influences endangering children and organizes and operates effective services aimed at the management of such 
influences as required, are established. It includes the individual case management of the endangered child, family in-team work aimed at eliminating the endangering factors, and the provision of services aimed at meeting the children's daily needs, or the full or partial takeover of the child's care on a temporary basis (Szöllősi, 2004).

In the events where child endangerment cannot be resolved through voluntary cooperation, or where the way in which the child is treated at home does not serve the child's interests, the child protection system applies the tool of intervention by the authorities to protect the child and enforce its rights. The first step at this level is that the way in which the child is taken care of at home is controlled by the competent authority; it means that the child is taken under the authority's protection and the social workers of the child welfare service are trying to help the family being under surveillance. If these measures fail to resolve the child endangerment situation, the authority will take the child out of its family and try to find the place of child care that is the most suitable for meeting the child's needs and ensuring its personal development, either in the child's own environment or by using special services of child protection (such as institutional care). The child is taken out of its family only for as long as absolutely necessary in order to establish the required conditions at home. To this end, for the duration of the child's placement outside its family the child welfare service applies the tools normally used by social workers, and provides services and benefits, in order to assist the family in eliminating the endangering factors and keeping in touch with the child and, finally, to help the child return to its family (Szöllősi, 2004; Fábián, Hüse \& Szoboszlai, 2012).

From January the 1rst 2016 family support and child welfare service must operate together in a professional and organizational system. This will work in settlements as family and child welfare services, and in districts as family and child welfare centres. The new roles demand intensified cooperation between the services and centres, moreover, the centres have to provide technical assistance for the child welfare services. The legislator purposes that the new roles also mean that family caregivers will have less overload in their work. There must be more time for the prevention programmes, family visits and helping the families in their everyday lives (e.g. team works, community development, and skills development). Since the changes, it shows that this intention have not materialized. The reason for that is still not clear, but it seems that it has connection with underfunding and the overload related to the increasing administrative work.

Consequently, the Hungarian child protection system tries to protect and serve children and their families on multiple levels. The child welfare service 
with its supporting and empowering role is in the first line of this multi-level system.

\section{The problem of street children in Hungary}

There is no generally accepted definition for 'street children' in Hungary. Although the three-fold definition by UNICEF ('children at risk', 'children on the street' and 'children of the street') is known to a small professional circle, this definition is not used either on social policy level or in child protection in practice. Instead, those children who are at the risk of becoming children of the street, or who spend a part of their day on the streets under endangering circumstances, are classified into subcategories. The categories applied may overlap (Ambrus, manuscript):

1. Children or adolescents who are in places inappropriate for their age, such as the streets of places of gambling or entertainment for adults, during school time, in the evening or during night hours.

2. Children with deviant behavior: children and adolescents who consume alcohol and narcotics on the streets and in public areas, act disorderly or live a life of crime. Children who damage their own health or may even commit suicide are included in this category.

3. Runaway youth. This category includes children who willfully leave a child care institution or their families without the permission of their legal representative (or guardian) for an extended period of time.

4. Children and adolescents who are abused. Due to the abuse they flee from home and find shelter at their friends or spend a few nights on the streets.

5. Underage prostitutes. The prostitution of children is considered to be serious endangerment requiring prompt measures: the children must be placed under the care of the appropriate institutions or the competent authorities.

6. Child beggars who work the streets either alone or with their parents or a gang of beggars, or possibly begging upon the order of others who pay a fee for such 'begging service'. This is considered as a critical situation since the child is not taken care of as it should be based on its needs, and at the same time the child does not receive the physical, emotional and moral care it needs and its socialization is also abused because this kind of socialization is not directed toward a norm accepted by the society but facilitates the interiorization of a deviant behavioral pattern instead. 
7. Homeless or extremely poor youth. Children, adolescents or expectant mothers who spend their nights on the streets or in public areas (that is, not in a room used for the purpose of dwelling).

The scene of social work is bound to be the community scene of this subculture, such as in shopping malls, other gathering places in the streets and around block of flats. Special methods are used in outreaching with children and adolescents who are lingering outside; creating a joint language, relying on peers, to understand one another; providing interesting programmes that might distract them from lingering in the street; arranging community events; opening and running youth offices and houses. Moreover, very often the usual family conflicts lie in the background of lingering around in the street, and thus children and adolescents may continue to stay away from home. Having provided safe conditions in a youth office or community house, the social worker can start using the methods of social casework, group work or community work to tackle at least some of the problems. The children lingering around may be greatly endangered since they lack both parental and school authority supervision; the scene where they tend to stay is unsafe, and in addition they are left alone to fulfill their own needs. Due to this situation of extremely high risk they may drift into crime, prostitution, trafficking as well as becoming victims of maltreatment. It is of great importance to reach them early and distract them from living in the street. In Hungary, settlements with over 40000 inhabitants provide this special street social work service for children, though few "best" practices have been established practice in this field. In some cases where the outreach with specialized programmes of street social work is effective, supportive work is provided by NGOs, the non-profit civil organizations (Fábián, Hüse \& Szoboszlai, 2012).

In Hungary, the category of children who live permanently on the streets is virtually nonexistent, with the exception of two small group. It could not say that it never happens in Hungary that a child spends the night on the streets or just away from its home, but the child care service can quickly find such abandoned children - often with the help of the local community - and provide them with the care they need. Although according to some experts the number of homeless people is around 25 to 30 thousand and the rooflesses are around 10 thousand (Győri, Gurály \& Szabó, 2014), this number does not really include children who permanently live the life of the homeless ( 80 percent of the homeless people are old or young males who lost their families). The child care service provides families who have lost their homes with temporary accommodation and intensive family preservation services aimed at ensuring that the family can have a new home and lead a life of their own within one or one and a half year. 
The two exception are the youths who mostly consume hard drugs and the immigrant children. The addicted youngsters usually join groups of other addicts and live, for an extended period of time, in the home of one of the group members by courtesy, or illegally occupy an apartment, or live the life of the homeless, depending on their circumstances. Since the consumption of narcotics is illegal in Hungary, drug addicts hide in abandoned places and are very difficult to find. The scope of roofless immigrant had implied a few beggar families from Romania over decades, but recently they are restricted. The child protect system mostly inadequate against both groups, the governmental actions cover them through the police or the health care system.

\section{The professional responses given to the issue of street children}

Coming back to the problem of children spending their time, or even the night, out on the streets, it is important to state that the Hungarian child protection system has woven a relatively strong safety net around endangered children in terms of both prevention and problem management. The elements of the safety net are the following:

1. The child welfare service focuses on primary care. Some 150,000 endangered children are registered by the child welfare system in Hungary (source: Hungarian Central Statistical Office, 2010). The tasks of the child welfare service are:

- providing information about the supports available

- counseling

- providing support for pregnant mothers who are in a crisis situation

- $\quad$ organizing free-time programs

- involvement in official investigations of abuse

- $\quad$ organizing a reporting and monitoring network

- $\quad$ providing family care

- preparing special proposals for special care if needed.

2. From the year 2004 onward, local governments, and the district municipalities of Budapest, of communities or districts with more than forty thousand permanent residents are required to operate a child welfare center. A child welfare center is an advanced version of the child welfare service, offering more special services such as street-based and residential area-based social work. 
The purpose of street-based child welfare social work is to provide special help for children spending their time and strolling about on the streets, and to find children who left their home intentionally or have been abandoned by their guardian and are not taken care of, help such abandoned children get back to their homes, and initiate their being taken under temporary care or provided with child protection services.

Street-based child-welfare social work is covered 26690 children allover the country in 2010 (Source: Hungarian Central Statistical Office, 2010).

3. Children's Temporary Home. The children's temporary home is a non-stop boarding institution where children are taken care of on a temporary basis by providing them with basic social services. The shelter can provide full board and lodging for a minimum of twelve and a maximum of forty children. Only those children are eligible to live in the children's temporary home who are not looked after by anyone temporarily, or would not be looked after if they were not taken to the children's temporary home, or who are not taken care of properly due to the family's life-coaching problems.

- In cooperation with the child welfare service, the children's temporary home assists in the return of the child to his or her family.

- The child is provided with this type of social service for as long as the circumstances that make the child eligible for these services exist but not for more than twelve months. When the statutory period of temporary care expires but it is still not possible for the child to return to its family, the child's stay at the children's temporary home may be extended - upon the parent's request - by six months, or, if necessary, until the end of the school year, or the Guardian Office must be requested without delay to take the necessary steps.

The Children's Temporary Home provides temporary social services for approximately 1,200 children in 2010 (Source: Hungarian Central Statistical Office, 2010).

4. Temporary home for families. It is a type of institution similar to the Children's Temporary Home but its primary purpose is to provide temporary accommodation for families with housing problems.

The temporary home for families provides temporary social services for approximately 6,200 children in 2010 (Source: Hungarian Central Statistical Office, 2010). 
5. Organization of alternative daytime and holiday programs. Such programs may be organized by the child welfare service or non-governmental organizations. Alternative day care as an important element of the primary care. Its major tasks are:

- to run useful free time programs

- the organization of special programs for different ages, interests, and other target groups

- day care for children.

- different group treatment for

-social integration,

-development of the community's consciousness

-strengthening of the community's responsiveness

The alternative day care has only a legal definition, but the Goverment does not provide sorurces per capita. The provision of this care is not an obligatory requirement by law, local government institutions are not provide. The alternative day care is been granted only NGOs throughout rhe country Recently, a significant portion of alternative day care services correct a lot of deficiency of other institutional services. The majority of satisfied needs under the alternative day care actually meet the lack of possibilities of public education and child protect system (Tóbiás, 2009).

5. System of special child protection services. The aim of these services is to provide a home for children who are taken out of their families temporarily or permanently, or have become orphans. This system provides for the bringing up of around 20,000 children (Source: Hungarian Central Statistical Office, 2010).

\section{Summary}

The renewed child protection system of Hungary has to face the greatest complexes of the social and economical problems during its two-decadeexistence. At the moment, the most important issue in Hungary seems to be the question of whether the child protection system is able to provide answers to the problems oppressing the life chances of a child. Also, it is important to consider whether the system of childcare is influential enough to direct societal attitudes in the right direction. Although the child protection care provides special care for children lingering on the street and who are involved in gangs, mostly far away from their homes and schools, the current question is whether the social work will be able to cope the burdens of poverty and segregation. However, the 
focused aim of street-work-service is able to reach out the children endangered by "street situation" and provides socialization and development programmes, the he real key of solution lies outside the scope of social work, but it is in the economical policy, labor market and education system.

This picture shows that the national child protection system does not give a really good answer to the problem of street children. The appropriate response is given by alternative services, but in the absence of financing is not implemented everywhere, at all times. In the light of the unmet needs of the children, it can see that the alternative services are much less wide-spread than it needs to justify it.

\section{References}

1. Ambrus Zs. (manuscript): Utcai szociális munka gyermekekkel, fiatalokkal. Módszertani útmutató.

2. Fábián G., Hüse L., Szoboszlai K. (2012): Modern Perspectives of Child Protection in Hungary. In: Hämäläinen, J., Littlechild, B., Chytil, O., Sramatá M., Jovelin E. [eds.]: Evolution of Child Protection and Child Welfare Policies in Selected European Countries. ERIS Monographs 2. University of Ostrava - ERIS, Ostrava. 181-201.

3. Győri P., Gurály Z., Szabó A. (2014): Gyorsjelentés a hajléktalan emberek 2014 február 3-i kérdőíves adatfelvételéről. Február Harmadika Munkacsoport. www.bmszki.hu/sites/default/files/field/...f-3-2014-sajto-tervezet2uj_adatokkal.ppt

4. Herczog M. (2001): Gyermekvédelmi kézikönyv. KJK-Kerszöv, Budapest.

5. Szöllősi G. [ed.] (2004): Gyermekjóléti alapellátás. Segédanyag a szociális szakvizsgához. NCSSZI, Budapest.

6. Tóbiás L. (2009): Gyermekek alternatív napközbeni ellátásának gyakorlata Magyarorszá-gon. Ph.D. értekezés. Eötvös Loránd Tudományegyetem Társadalomtudományi Kar Szo-ciológiai Doktori Iskola Szociálpolitikai program.

Author

Hüse Lajos föiskolai docens

Debreceni Egyetem Egészségügyi Kar

huse.lajos@foh.unideb.hu 